\title{
PEMETAAN RESISTENSI NYAMUK AEDES sp TERHADAP MALATION DAN KEPADATAN VEKTOR DEMAM BERDARAH DENGUE (DBD) DI SULAWESI UTARA
}

\author{
Steven Jacub Soenjono, Suwarja, Joy Victor Imanuel Sambuaga \\ (Poltekkes Kemenkes Manado)
}

\begin{abstract}
The event of mosquito immunity or resistance to malation is one of the main inhibitors of chemical eradication of vectors with insecticides. Vector resistance to insecticides is a global phenomenon, especially for managers of vector-borne control programs in Indonesia. The aims of this study was to map the resistance of Aedes sp mosquitoes to the malation and vector density of Dengue Hemorrhagic Fever (Aedes sp) in North Sulawesi Province in 2019. This research was descriptive in order to obtain a description of pre-adult vector density and to map the status of Dengue Hemorrhagic Fever vector resistance (Aedes sp) against malation. Resistance status data using data from 2015-2018 research. The population in this study are houses in North Minahasa Regency, Minahasa Regency, Tomohon City, Bitung City and Manado City. The sample for vector density is a larva survey of 100 resident houses which includes case houses and houses around DHF cases. North Minahasa Regency (Wautumou Village), Minahasa Regency (Papakelan Village), Tomohon City (Rurukan Village), Bitung City (Girian Permai Village), Manado City (Malalayang Village 2). Determination of the sample based on the highest case in each district in the city during the DHF vector resistance test in 2015-2018. The results showed that the average density of $\mathrm{HI}$ vectors (31.\%), $\mathrm{BI}(17.5)$ and $\mathrm{Cl}(34.8 \%)$ with resistance status in the four districts of the mosquito vector city of DHF were resistant and one district (North Minahasa) with a vulnerable status. Resistance and density vectors are digitally mapped.
\end{abstract}

Keywords: Mapping; resistance; Malation; Vector Density

\begin{abstract}
Abstrak
Kejadian kekebalan atau resistensi nyamuk terhadap malasi adalah salah satu penghambat utama pemberantasan kimiawi vektor dengan insektisida. Resistensi vektor terhadap insektisida adalah fenomena global, terutama bagi para manajer program pengendalian vektor di Indonesia. Tujuan dari penelitian ini adalah untuk memetakan resistensi nyamuk Aedes sp terhadap malasi dan kepadatan vektor Demam Berdarah Dengue (Aedes sp) di Provinsi Sulawesi Utara pada tahun 2019. Penelitian ini bersifat deskriptif untuk mendapatkan deskripsi vektor pra-dewasa kepadatan dan untuk memetakan status resistensi vektor Dengue Hemorrhagic Fever (Aedes sp) terhadap malation. Data status resistensi menggunakan data dari penelitian 2015-2018. Populasi dalam penelitian ini adalah rumah-rumah di Kabupaten Minahasa Utara, Kabupaten Minahasa, Kota Tomohon, Kota Bitung, dan Kota Manado. Sampel untuk kepadatan vektor adalah survei larva terhadap 100 rumah penduduk yang meliputi rumah kasus dan rumah di sekitar kasus DBD. Kabupaten Minahasa Utara (Desa Wautumou), Kabupaten Minahasa (Desa Papakelan), Kota Tomohon (Desa Rurukan), Kota Bitung (Desa Girian Permai), Kota Manado (Desa Malalayang 2). Penentuan sampel berdasarkan kasus tertinggi di setiap kabupaten di kota selama uji resistensi vektor DBD pada 2015-2018. Hasil penelitian menunjukkan bahwa kepadatan rata-rata vektor $\mathrm{HI}$ (31.\%), BI (17.5) dan $\mathrm{Cl}$ (34.8\%) dengan status resistensi di empat kabupaten kota vektor nyamuk DBD tahan dan satu kabupaten (Minahasa Utara) dengan status rentan. Vektor resistensi dan kepadatan dipetakan secara digital.
\end{abstract}

Kata Kunci : Pemetaan; resistensi; Malation; Kepadatan Vektor 


\section{PENDAHULUAN}

Data Profil Kesehatan Dinkes Provinsi Sulawesi Utara tahun 2017 menunjukkan bahwa kasus DBD tercatat ada 2.217 kasus DBD meningkat dibandingkan tahun 2015 dengan 1.562 kasus DBD yang terjadi di wilayah Sulawesi Utara dengan jumlah kematian adalah 17 kasus atau angka kematian (CFR) sebesar 0,8. Peningkatan kasus ini dipengaruhi oleh faktor perubahan musim, tingkat kesadaran dan pengetahuan masyarakat yang masih kurang tentang pemberantasan sarang nyamuk (PSN) dan manajemen pengendalian kasus serta peran surveilans yang perlu ditingkatkan ${ }^{1}$.

Obat dan vaksin pencegah DBD hingga saat ini belum ditemukan, maka upaya pemberantasan penyakit DBD dititikberatkan pada pemberantasan nyamuk disamping kewaspadaan dini terhadap kasus DBD. Pengendalian vektor DBD yang selama ini telah dilakukan adalah pengendalian nyamuk dewasa melalui fogging menggunakan malation. Pelaksanaan survei entomologi terhadap tempat-tempat perkembangan jentik DBD sudah sering dilaksanakan tetapi tidak berkesinambungan sehingga keberadaan tempat perindukan selalu tersedia,didukung oleh perilaku masyarakat dengan membuang sampah sembarangan sehingga secara tidak langsung mendukung keberadaan perindukan nyamuk vektor DBD. Survei entomologi sangat penting peranannya untuk memprediksi kepadatan vektor yang pada akhirnya dapat mempertajam pelaksanaan program pengendalian DBD.

Pengendalian vektor secara kimiawi, khususnya pemberantasan vektor yang menggunakan insektisida, yang digunakan untuk pemberantasan nyamuk akan merangsang terjadinya seleksi pada populasi serangga yang menjadi sasaran. Nyamuk yang rentan terhadap insektisida bersangkutan akan mati, sedangkan yang kebal akan tetap hidup. Jumlah yang hidup ini lama kelamaan akan bertambah banyak, sehingga terjadilah perkembangan kekebalan nyamuk terhadap insektisida yang bersangkutan. Penelitian yang dilakukan di Jawa Tengah menunjukkan bahwa Aedes aegypti sudah resisten terhadap malation $^{2,3}$. Peristiwa kekebalan ini merupakan salah satu penghambat utama pemberantasan vektor secara kimiawi dengan insektisida ${ }^{4}$.

Sejak tahun 2015 sudah dilaksanakan uji resistensi pada beberapa kabupaten/kota di Sulawesi Utara, yaitu Kabupaten Minahasa Utara, Kabupaten Minahasa, Kota Tomohon, Kota Bitung dan Kota Manado.Hasil uji menunjukkan bahwa nyamuk Aedes sp pada kelima kabupaten/kota tersebut sudah resisten (kecuali Kabupaten Minahasa Utara) terhadap insektisida malation yang digunakan ${ }^{5}$. Hasil uji resistensi tersebut sangat dimungkinkan memberikan kontribusi peningkatan kasus pada setiap kabupaten/kota karena tidak dapat mengendalikan nyamuk Aedes sp dewasa pada saat penyemprotan insektisida menggunakanmalation.

Pemetaan terhadap resistensi nyamuk Aedes sp terhadap malation penting dilakukan untuk mendukung kegiatan pengamatan, pengendalian vektor penyakit dan dapat 
memperbaiki sistem informasi dengan memberikan gambaran sebaran resistensi nyamuk Aedes sp melalui dukungan informasi yang lebih baik untuk perencanaan, monitoring, evaluasi serta pengambilan keputusan dalam program pengendalian DBD selanjutnya.

\section{METODE PENELITIAN}

Penelitian ini bersifat deskriptif untuk mendapatkan gambaran kepadatan vektor pra dewasadan memetakan status resistensi nyamuk Demam Berdarah Dengue (Aedes $\mathrm{sp}$ ) terhadap malation. Data status resistensi menggunakan data hasil penelitian tahun 20152018. Populasi dalam penelitian ini adalah rumah di Kabupaten Minahasa Utara, Kabupaten Minahasa, Kota Tomohon, Kota Bitung dan Kota Manado.Sampel untuk kepadatan vektor adalah survei jentik 100 rumah penduduk yangdipilih secara purposif, rumah kasus dan rumah di sekitar kasus DBD di Kabupaten Minahasa Utara (Desa Wautumou), Kabupaten Minahasa (Desa Papakelan), Kota Tomohon (kel Rurukan), Kota Bitung (Kelurahan Girian Permai), Kota Manado (Kelurahan Malalayang 2). Penentuan desa/kelurahan berdasarkan kasus tertinggi di masing-masing kabupaten kota pada saat dilakukan uji resistensi vektor DBD tahun 2015-2018.Alat yang digunakan untuk pengambilan titik koordinatmenggunakan GPS dan diolah menggunakan perangkat komputer aplikasi Arc. GIS versi 9.3

\section{HASIL PENELITIAN}

Data hasil survei kepadatan vektor demam berdarah dengue (DBD) dengan parameter House Index $(\mathrm{HI})$, Breteau Index $(\mathrm{BI})$ dan Countainer Index $(\mathrm{Cl})$ dan status resistensi nyamuk Aedes sp terhadap malation berdasarkan Kabupaten Kota di Sulawesi Utara dapat dilihat pada tabel 1.

\begin{tabular}{|c|c|c|c|c|c|}
\hline \multirow[t]{2}{*}{ No } & \multirow[t]{2}{*}{ Kabupaten/Kota } & \multicolumn{3}{|c|}{ Kepadatan Vektor } & \multirow{2}{*}{$\begin{array}{c}\text { Status } \\
\text { Resistensi }\end{array}$} \\
\hline & & $\mathrm{HI}$ & $\mathrm{BI}$ & $\mathrm{Cl}$ & \\
\hline 1 & Minahasa Utara & $44 \%$ & 18 & $35 \%$ & Rentan \\
\hline 2 & Tomohon & $35 \%$ & 16 & $26 \%$ & Resisten \\
\hline 3 & Bitung & $44 \%$ & 21.4 & $73 \%$ & Resisten \\
\hline 4 & Minahasa & $11 \%$ & 19.7 & $16 \%$ & Resisten \\
\hline \multirow[t]{2}{*}{5} & Manado & $25 \%$ & 12.6 & $23.8 \%$ & Resisten \\
\hline & Rata-rata & $31.5 \%$ & 17.5 & 34,8 & \\
\hline
\end{tabular}

Data kepadatan vektor demam berdarah dengue (DBD) menunjukkan bahwa Kota Bitung memiliki kepadatan tinggi sementara kabupaten/kota yang lain memiliki kepadatan sedang. Status resistensi nyamuk Aedes sp terhadap malation menunjukkan bahwa empat kabupaten/kota menunjukkan bahwa nyamuk Aedes sp sudah resisten terhadap malation, 
kecuali Kabupaten Minahasa Utara masih rentan. Hasil di atas selanjutnya ditampilkan dalam bentuk pemetaan sebagai berikut :
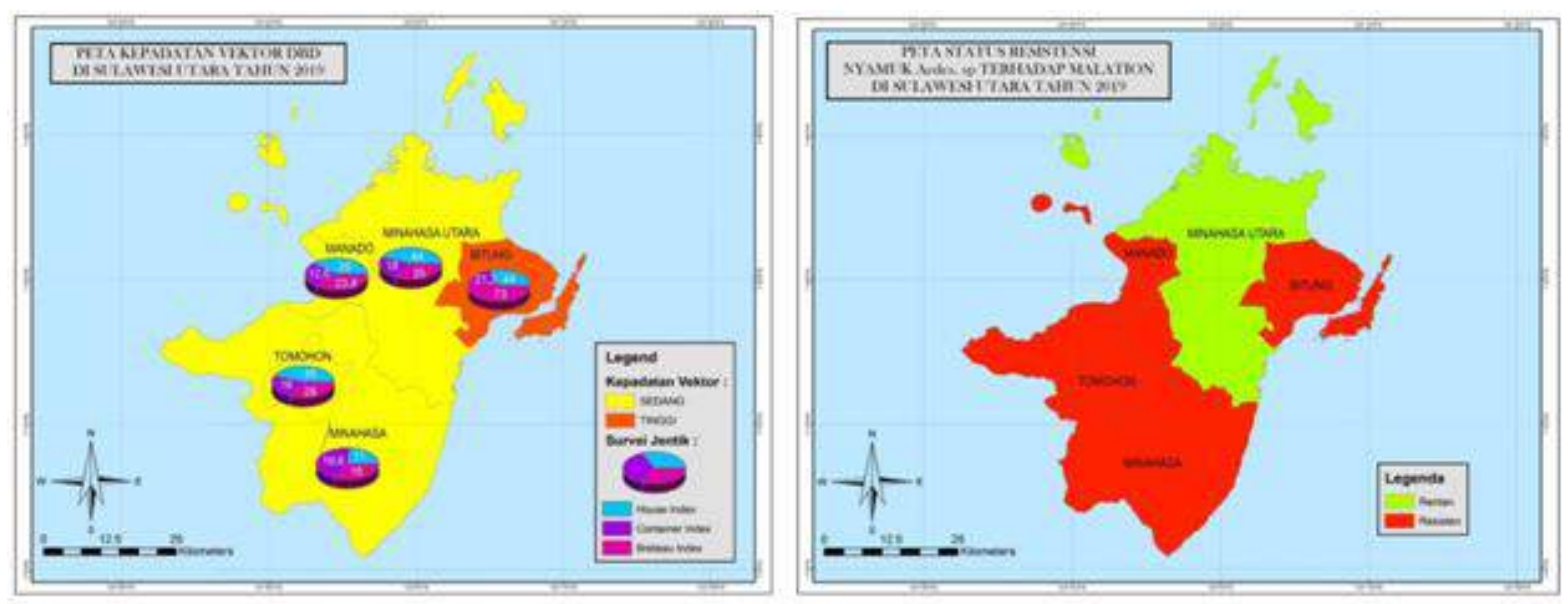

Gambar 1. Peta kepadatan dan status resistensi vektor DBD berdasarkan Kabupaten/Kota di Sulawesi Utara

\section{PEMBAHASAN}

Survei terhadap kepadatan larva Aedes sp yang sudah dilakukan terhadap beberapa indikator kepadatan vektor DBD di lima kabupaten dan kota di Sulawesi Utara menunjukkan bahwa rata-rata nilai House Index $(\mathrm{HI})$ sebesar31,5\%. Angka ini tidak aman terkait penularan penyakit, karena "zona aman" terkait penularan penyakit di daerah tropis yaitu $\mathrm{HI} \leq 5 \%{ }^{16}$. Indikator $\mathrm{Cl}$ dan $\mathrm{BI}$ menunjukkan rata-rata 17,5\% dan 34,8. Angka-angka tersebut jika disesuaikan dengan tabel density figure masuk dalam kategori kepadatan sedang karena berada pada tingkat 4 dan $5^{16}$. Hasil penelitian ini lebih tinggi dibandingkan penelitian di Kelurahan Cicadas Bandungdimana ditemukan $\mathrm{HI} 22,22 \%$, Cl 12,84\% BI 27,45 dan penelitian di Desa Gergunung Kabupaten Klaten dimana ditemukan HI 19,2\%, Cl 1,6\% BI 27,9. Iniberarti bahwa kepadatan vektor DBD yang ada maka Sulawesi Utara mempunyai risiko terjadinya transmisi virus dengue atau penularan penyakit DBD lebih tinggi dibandingkan di Kelurahan Cicadas Bandung dan Desa Gergunung Kabupaten Klaten ${ }^{6,7}$. Lebih lanjut dijelaskan bahwa bila $\mathrm{DF}>1, \mathrm{HI}>1$ dan $\mathrm{Bl}>5$ menunjukkan resiko terjadinya penularan atau transmisi penyakit Demam Berdarah Dengue (DBD) di daerah tersebut ${ }^{6}$.

Berdasarkan indikator tersebut maka Sulawesi Utara termasuk daerah yang memiliki transmisi virus dengue tinggi karena $\mathrm{Cl}$ lebih besar $10 \%$. Meskipun untuk angka $\mathrm{Bl}<50$ yang mempunyai risiko rendah terhadap terjadinya transmisi virus dengue tetapi bukan berarti Sulawesi Utara bebas DBD karena angka $\mathrm{HI}$ dan $\mathrm{Cl}$ tinggi. Hal ini sangat memungkinkan penularan penyakit DBD di daerah ini menjadi tinggi, ini dibuktikan dengan penelitian di Singkil Manado yang menunjukkan angka Density Figure (DF) dengan kepadatan tinggi ${ }^{17}$.Dalam rangka menekan penyebaran penyakit DBD serta mengurangi dampak 
ekonomis maupun kesehatan masyarakat akibat penyakit DBD, melalui strategi khusus salah satunya adalah mengurangi tempat-tempat perindukan nyamuk Aedes sp.

Hasil uji resistensi di Sulawesi Utara khususnya di lima kabupaten dan kota, yaitu Kabupaten Minahasa Utara, Kabupaten Minahasa, Kota Tomohon, Kota Bitung dan Kota Manado menunjukkan bahwa rata-rata nyamuk Aedes sp sebagai vektor Demam Berdarah Dengue (DBD) Kabupaten/Kota tersebut sudah resisten terhadap malation, kecuali Kabupaten Minahasa Utara. Hal tersebut terjadi karena insektisida ini telah digunakan dalam jangka waktu lama dengan frekuensi yang tinggi ${ }^{4,8,9}$. Hasil uji ini sangat penting sebagai bahan informasi dalam rangka pengawasan dan pengendalian penyakit DBD di Sulawesi Utara. Status kepadatan vektor DBD yang rata-rata menunjukkan kepadatan tinggi dan sedang serta status resistensi nyamuk Aedes $s p$ terhadap malation menambah tanda awas bagi penularan penyakit DBD.Daerah-daerah ini harus mendapat perhatian khusus karena vektor DBD sudah mengalami resistensi terhadap malation. Tentu saja hal ini dapat menghambat pemberantasan DBD.

Salah satu faktor yang sangat berpengaruh terhadap peningkatan status resistensi suatu populasi nyamuk adalah sifat dari nyamuk itu sendiri. Sifat nyamuk yang mendukung adalah populasi nyamuk yang dinamis, kemampuan beradaptasi dan berevolusi yang tinggi. Nyamuk juga mempunyai kecepatan reproduksi yang tinggi dan mempunyai masa generasi yang pendek sehingga nyamuk mudah mengalami mutasi genetik. Semakin banyak jumlah generasi pertahun, kecepatan resistensi akan makin cepat ${ }^{10}$.Hal ini dibuktikan dengan laporan penelitian yang menunjukkan bahwa perubahan tingkat resistensi Ae. aegypti menjadi 3,2 kali setelah generasi ke- $45^{11}$. Selain malathion, insektisida lain seperti permetrin menunjukkan terjadi peningkatan resistensi terhadap nyamuk Ae. aegypti menjadi 5-18 kali setelah 5 generasi ${ }^{18}$.

Kecenderungan masyarakat lebih senang di-fogging rumahnya, bahkan beberapa masyarakat melakukan protes jika dalam periode tertentu tidak dilakukan fogging apalagi ketika terdengar kasus DBD mulai muncul atau musim penghujan mulai turun. Metode yang paling sering digunakan oleh instansi terkait, Dinas Kesehatan dan Puskesmas adalah melakukan fogging pada saat terjadi kasus dan metode ini menjadi cara utama untuk mengendalikan penularan DBD, semestinya tidak perlu menunggu kasus, tidak perlu menunggu musim hujan untuk bersikap waspada, sepanjang tahun masyarakat dibina dan dibiasakan untuk melakukan pemberantasan sarang nyamuk (PSN) sebagai suatu metode paling murah dengan tingkat keberhasilan yang tinggi, jika PSN ini jadi budaya di masyarakat maka pengendalian vektor DBD tidak perlu menggunakan bahan kimia dan tentunya juga tidak akan terjadi resistensi pada nyamuk vektor DBD.

Upaya pemetaan kejadian penyakit DBD dalam epidemiologi penting dilakukan untuk mengetahui pola distribusi penyakit, wilayah berisiko tinggi dan faktor risiko suatu penyakit 
secara kewilayahan, sehingga upaya pengendalian penyakit dapat dilakukan dengan tepat $^{12}$. Penelitian di wilayah kerja Puskesmas Kedungmundu sebagai daerah endemis DBD menunjukkan bahwa sebaran kasus DBD memiliki keterkaitan secara spasial dengan kepadatan penduduk ${ }^{13}$. Penelitian ini berperan penting dalam mengetahui peranan pemetaan resistensi insektisida terhadap program pengawasan dan pengendalian terjadinya infeksi dengue di Propinsi Sulawesi Utara. Oleh karena itu, dibutuhkan pemetaan penyakit DBD berbasis spasial untuk mengetahui wilayah yang rentan DBD sehingga dapat menjadi acuan dalam penentuan lokasi fogging ${ }^{14,15}$.

\section{SIMPULAN DAN SARAN}

Dipetakannya secara digital kepadatan 5 kabupaten dan kota di Sulawesi Utara, yaitu Kabupaten Minahasa Utara, Kota Tomohon, Kota Bitung, Kota Manado dan Kabupaten Minahasa dengan hasil kepadatan rata-rata vektor $\mathrm{HI}$ (31.\%), Bl (17.5) dan $\mathrm{Cl}$ (34.8\%) dengan status resistensi di empat kabupaten kota vektor nyamuk DBD tahan dan satu kabupaten (Minahasa Utara) dengan status rentan. Vektor resistensi dan kepadatan dipetakan secara digital.

Disarankan kepada masyarakat terutama di empat kabupaten kota yang didapati nyamuk vektor DBD sudah resisten harus lebih waspada terhadap kejadian DBD, membudayakan diri sadar akan kebersihan lingkungan dengan melaksanakan pemberantasan sarang nyamuk (PSN) untuk semua warga, karena pengendalian pada saat terjadi kasus dengan menggunakan malation tidak akan menghentikan penularan kasus DBD karena nyamuk tidak mempan lagi dengan malation yang biasa digunakan sudah resisten. Kepada pihak terkait (Dinas Kesehatan dan Puskesmas) segera melakukan rotasi terhadap malation dengan mengganti insektisida dari kelompok dan jenis yang berbeda.

\section{DAFTAR PUSTAKA}

1. Dinkes Provinsi Sulut. Profil Kesehatan Propinsi Sulawesi Utara. Manado; 2017.

2. Sunaryo, Ikawati B, Rahmawati, Widiastuti D. Status Resistensi Vektor Demam Berdarah Dengue (Aedes aegypti) Terhadap Malation 0,8\% dan Permetrin 0,25\% Di Jawa Tengah. J Ekol Kesehat. 2014;13(2):146-52.

3. Ikawati B, Sunaryo, Widiastuti D. Peta Status Kerentanan Aedes aegypti (Linn) Terhadap Insektisida Cypermetrin dan Malation Di Jawa Tengah. Aspirator. 2015;7(1):23-8.

4. Widiarti, Heriyanto B, Boewono DT, Widiyastuti U, Mujiono, Lasmiyati, et al. Peta Resistensi Vektor Demam Berdarah Dengue Aedes aegyti Terhadap Insektisida kelompok Organofofat, Karbamat dan Piretroid di Propinsi Jawa Tengah dan Daerah Istimewa Yogyakarta. J Bul Penelit Kesehat. 2011;39(4):176-89. 
5. Soenjono SJ, Suwarja, Pandean MM. Status Resistensi Vektor Demam Berdarah Dengue (Aedes aegypti) Terhadap Malation di Kota Tomohon. J Vektor Penyakit. 2017;11(2):1-7.

6. Ariva, Lini dan Oginawati, Katharina. Identifikasi Density Figure dan Pengendalian Vektor Demam Berdarah pada Kelurahan Cicadas Bandung. Jurnal Teknik Lingkungan. 2013;19(1):55-63.

7. Pascawati NA, Songjanan EP, Satoto TB, Delta Elisabeth. Analisis Faktor Keberadaan Vektor Penular DBD melalui Identifikasi Tempat Potensial Perkembangbiakan Nyamuk Aedes Sp. Di Desa Gergunung, Kabupaten Klaten, Jawa Tengah. Jurnal Manajemen Kesehatan Indonesia. 2018;6(1):29-38.

8. Safitri. Pemetaan, Karakteristik Habitat dan Status Resistensi Aedes aegypti Di Kota Banjarmasin Kalimantan Selatan. VEKTORA. 2013;3(2):136-48.

9. Prasetyowati H, Hendri J, Wahono T. Status Resistensi Aedes aegypti (Linn.) terhadap Organofosfat di Tiga Kotamadya DKI Jakarta. BALABA. 2016;12(1):23-30.

10. Ahmad I. Adaptasi serangga dan dampaknya terhadap kehidupan manusia. 2011.

11. Hidayati $H$, Nazni WA, Lee HL, Sofian-zirunM. Insecticide resistance development in Aedes aegypti upon selection pressure with malathion.Trop Biomed. 2011;28(2):42537.

12. Purnama SG, Baskoro T, Prabandari Y. Pemetaan Spasial Kasus Infeksi Dengue dan Uji Kerentanan Aedes aegypti pada Organofosfat. Ilmu Kesehat Masy. 2013;4(2):14857.

13. Kusuma AP dan Sukendra DM. Analisis Spasial Kejadian Demam Berdarah Dengue Berdasarkan Kepadatan Penduduk. Unnes Journal of Public Health. 2016;5(1):48-56.

14. Syamsir, Daramusseng A. Analisis Spasial Efektifitas Fogging Di Wilayah Kerja Puskesmas Makroman, Kota Samarinda. J Nas Ilmu Kesehat. 2018;1(2):1-7.

15. Ruliansyah A, Gunawan T, Sugeng Juwono M. Pemanfaatan Citra Penginderaan Jauh dan Sistem Informasi Geografis untuk Pemetaan Daerah Rawan Demam Berdarah Dengue (Studi Kasus di Kecamatan Pangandaran Kabupaten Ciamis Provinsi Jawa Barat). J Aspirator. 2011;3(2):72-81.

16. Queensland Government. The Queensland Dengue Management Plan 2010-2015. Fortitude Valley : Queensland Health, 2011.

17. Sorisi AMH dan Pijoh VD. Larval Density of Aedes spp. in Residential Areas of Singkil District, Manado City, Indonesia. TMJ. 2017;04(1):43-47.

18. Mantolu Y, Kustiati, Ambarningrum TB, Yusmalinar S, Ahmad I. Status dan Perkembangan Resistensi Aedes aegypti (Linnaeus) (Diptera: Culicidae) Strain Bandung, Bogor, Makassar, Palu dan VCRU Terhadap Insektisida Permetrin dengan Seleksi Lima Generasi. J Entomologi Indonesia. 2016;13(1):1-8. 